\title{
Annual Reviews of Computational Physics VII
}




\title{
annual Reviews of computational physics
}

Series Editor: Dietrich Stauffer (Cologne University)

\author{
Published: \\ Vol. I: ISBN 981-02-1881-8 \\ Vol. II: ISBN 981-02-2176-2 \\ Vol. III: ISBN 981-02-2427-3 \\ ISBN 981-02-2506-7 (pbk) \\ Vol. IV: ISBN 981-02-2728-0 \\ ISBN 981-02-2753-1 (pbk) \\ Vol. V: ISBN 981-02-3181-4 \\ ISBN 981-02-3182-2 (pbk) \\ Vol. Vl: ISBN 981-02-3563-1 \\ Vol. VII: ISBN 981-02-4080-5
}




\section{Annual Reviews of Computational Physics VII}

edited by

Dietrich Stauffer

Cologne University 


\title{
Published by
}

World Scientific Publishing Co. Pte. Lid.

P O Box 128, Farrer Road, Singapore 912805

USA office: Suite 1B, 1060 Main Street, River Edge, NJ 07661

UK office: 57 Shelton Street, Covent Garden, London WC2H 9HE

\section{British Lbrary Cataloguing-ln-Publication Data}

A catalogue record for this book is available from the British Library.

\begin{abstract}
aNNUAL REVIEWS OF COMPUTATIONAL PHYSICS VII
Copyright $\bigcirc 2000$ by World Scientific Publishing Co. Pte. Ltd.

All rights reserved. This book, or parts thereof, may not be reproduced in any form or by any means, electronic or mechanical, including photocopying, recording or any information storage and retrieval system now known or to be invented, without written permission from the Publisher.
\end{abstract}

For photocopying of material in this volume, please pay a copying fee through the Copyright Clearance Center, Inc., 222 Rosewood Drive, Danvers, MA 01923, USA. In this case permission to photocopy is not required from the publisher.

ISBN 981-02-4080-5

Printed in Singapore by Uto-Print 


\section{PREFACE}

Applications dominate this seventh volume of the series: from Ising models to the formation of small clusters and phase ordering in fluids, to the structure of concrete, to the growth of cities built from it, to the traffic jams and the biology of life in the cities, and to the marketing of products to consumers. Thus the interdisciplinary research potential of computational physics is particularly well documented. The cover picture, from Simon et al., Int. J. Mod. Phys. C10, 4, shows traffic simulations in the city of Portland, Oregon, USA, as described in the review of Nagel et al.

As in the past, all articles were with the publisher the day after the deadline. Suggestions and self-nominations for future articles should be sent to stauffer@thp.uni-koeln.de.

Cologne, June 1999

Dietrich Stauffer 
This page is intentionally left blank 


\section{CONTENTS}

Preface $\quad$ v

Dietrich Stauffer

The Simulation of the Ising Model on the Creutz Cellular Automaton 1 N. Aktekin

Lennard-Jones Clusters and the Multiple-Minima Problem

L. T. Wille

Phase Ordering in Fluids

J. M. Yeomans

Computer Simulation and Percolation Theory Applied to Concrete

E. J. Garboczi and D. P. Bentz

Computer Simulations in Urban Geography

L. Benguigui

Large-Scale Traffic Simulations For Transportation Planning

K. Nagel, J. Esser and M. Rickert

Biological Evolution Through Mutation, Selection, and Drift: An

Introductory Review

E. Baake and W. Gabriel

An Evolutionary Model for Simple Ecosystems

F. Bagnoli and M. Bezzi

Microscopic Simulation of Reaction-Diffusion Processes and Applications of Population Biology and Product Marketing

E. Bettelheim and B. Lehmann 